DEPARTMENT OF THE INTERIOR

UNITED STATES GEOLOGICAL SURVEY

\title{
GEOLOGIC MAP OF THE CANYON OF LODORE SOUTH QUADRANGLE, MOFFAT COUNTY, COLORADO
}

By Wallace R. Hansen 


\section{GEOLOGIC MAP SYMBOLS}

\section{COMMONLY USED ON MAPS OF THE UNITED STATES GEOLOGICAL SURVEY}

(Special symbols are shown in explanation)

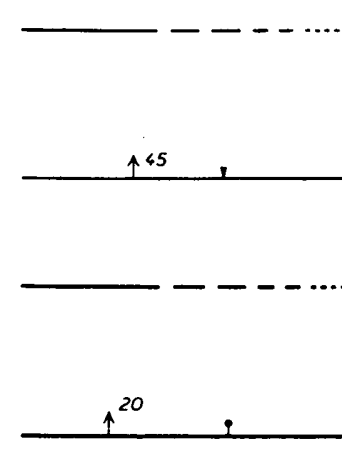

Contact - Dashed where approximately located; short dashed where inferred; dotted where concealed

Contact - Showing dip; well exposed at triangle

Fault - Dashed where approximately located; short dashed where inferred; dotted where concealed

Fault, showing dip - Ball and bar on downthrown side

Normal fault - Hachured on downthrown side

Fault - Showing relative horizontal movement

Thrust fault - Sawteeth on upper plate

Anticline - Showing direction of plunge; dashed where approximately located; dotted where concealed

Asymmetric anticline - Short arrow indicates steeper limb

Overturned anticline - Showing direction of dip of limbs

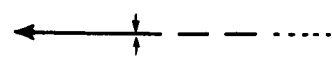

Syncline - Showing direction of plunge; dashed where approximately located; dotted where concealed

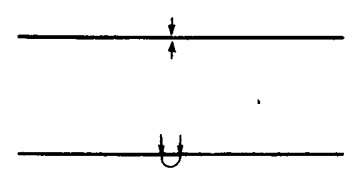

Asymmetric syncline - Short arrow indicates steeper limb

Overturned syncline - Showing direction of dip of limbs

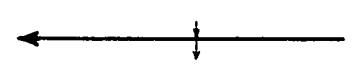

Monocline - Showing direction of plunge of axis

$\rightarrow \rightarrow^{20} \quad$ Minor anticline - Showing plunge of axis

$\leftrightarrow{ }^{60} \quad$ Minor syncline - Showing plunge of axis
Strike and dip of beds - Ball indicates top of beds known from sedimentary structures

$\stackrel{70}{10}$ Inclined $\oplus$ Horizontal

+ Vertical $\stackrel{40}{40}$ Overturned

Strike and dip of foliation 20 Inclined $\rightarrow$ Vertical $\downarrow$ Horizontal

Strike and dip of cleavage

15 Inclined $\longmapsto$ Vertical $f$ Horizontal

Bearing and plunge of lineation

$15 \longleftarrow$ Inclined $\bullet$ Vertical $\longleftrightarrow$ Horizontal

Strike and dip of joints - 40 Inclined $\rightarrow$ Vertical + Horizontal

Note: planar symbols (strike and dip of beds, foliation or schistosity, and cleavage) may be combined with linear symbols to record data observed at same locality by superimposed symbols at point of observation. Coexisting planar symbols are shown intersecting at point of observation.

Shafts

vertical $\$$ Inclined

Adit, tunnel, or slope

$\succ$ Accessible $\nsim$ Inaccessible

$x$ Prospect

Quarry

A Active Abandoned

Gravel pit

$\times$ Active $\Varangle$ Abandoned

Oil well

- Drilling $\phi$ Shut-in $\&$ Dry hole

*as Show of gas abandoned

- Oil Show of oil 